\title{
Who suffers and how much from corruption? Evidence from firm-level data
}

\author{
Andrzej Cieślik ${ }^{1}$ (D) · Łukasz Goczek ${ }^{1}$
}

Received: 4 June 2020 / Revised: 8 January 2021 / Accepted: 7 April 2021 /

Published online: 27 May 2021

(c) The Author(s) 2021

\begin{abstract}
In this article, we study firm-level determinants of corruption using a sample of 164,000 companies from 144 countries for the 2005-2020 period. We analyze two variables related to corruption: the perception of corruption as an obstacle to doing business using an ordinal logit model and actual bribe tax payments using a fractional logit model. Controlling for other factors, both sets of our empirical results show that the extent of corruption is related to the time spent dealing with regulations and inspections. We argue that firms which spend more time dealing with administrative procedures have a greater perception of corruption and are forced to make significantly higher bribe payments. Therefore, in a successful fight against corruption, it is essential to simplify administrative procedures by reducing their number and eliminating direct contacts between firms and officials.
\end{abstract}

Keywords Corruption · Firm-level data $\cdot$ Developing countries

JEL Classification D02 $\cdot \mathrm{K} 42 \cdot \mathrm{L} 14 \cdot \mathrm{M} 48 \cdot \mathrm{P} 37$

\section{Introduction}

Corruption is an important obstacle to economic development. Cieślik and Goczek (2018a) show that corruption hurts economic growth and lowers the investment to GDP ratio. They argue that corruption hampers investment by increasing uncertainty about investment returns and property rights. Higher corruption is associated with higher transaction costs, higher inflation, and lower individuals' incentive to invest (Gründler and Potrafke 2019). Although individual firms can benefit from getting

Andrzej Cieślik

cieslik@wne.uw.edu.pl

Łukasz Goczek

lgoczek@wne.uw.edu.pl

1 Faculty of Economic Sciences, University of Warsaw, ul. Dluga 44/50, 00-241 Warsaw, Poland 
public contracts (Cheung et al. 2012), mitigating excessive regulations (Huntington 1968), and speeding up administrative processes (Lui 1985), these benefits may not be gained by all if bureaucrats extort bribes by intentionally creating a worse business environment for everyone-by decreasing the speed and quality of their decisions (Ahlin and Bose 2007; Sylwester 2019).

Therefore, the goal of this article is to study the relationships among the perception of corruption, bribe tax paid by individual firms, and firm and institutional characteristics in 144 countries. To study these relationships, we refer to a theoretical model of stalled bureaucratic decisions proposed by Ahlin and Bose (2007) and use a sample of 164,000 companies for the 2005-2020 period to verify its predictions. The sample is obtained from the recent World Bank Enterprise Survey. In our empirical study, we employ two variables as measures of corruption: (1) the perception of corruption as an obstacle to doing business and (2) actual bribe tax payments declared by firms. Furthermore, to test the robustness of our results, we model a two-step decision using the Heckman self-selection model: first, whether a firm engages in dealings with state officials and, second, how much it pays as a fraction of sales.

In Sect. 2 we survey the literature on corruption. In Sect. 3 we describe the theoretical framework. In Sect. 4 we discuss the empirical methodology. In Sect. 5 we report our estimation results. Section 6 summarizes and concludes with policy recommendations aimed at limiting corruption.

\section{Literature review}

Corruption is generally analyzed as a social phenomenon, especially in comparative research, however, corruption starts with economic decisions made by individuals colluding to cheat a third party. As long as this takes place voluntarily, the colluding parties are better off. If externalities for the third party are lower than the gain of the two parties' corruption can be efficiency-enhancing. In this way, it could be thought of as a rational market response to a preexisting government failure. Based on this second-best logic, it has been argued that corruption allows firms to go around the red tape and misconceived regulations to speed up bureaucratic procedures and promote allocative efficiency (Huntington 1968; Leff 1964).

This is formalized in a queueing model proposed by Lui (1985) and an auction model proposed by Beck and Maher (1986). In the queue model, a bureaucrat allocates licenses to agents who queue to obtain them. The effort required to serve a client is a disincentive to a bureaucrat and causes delays. Those, who profit most, dislike the queue the most, so they bid the highest bribe to jump over the line. This as-if market mechanism minimizes the time costs of the queue. This argument was opposed by Myrdal (1968) who argued that officials purposely cause administrative delays to attract more bribes. A similar proposition was formalized by RoseAckerman (1978), who argued that bureaucrats are monopolists who set prices by deliberately creating scarcity in their services. Therefore, the queue model overlooks the discretion that politicians and bureaucrats have over the formation and 
implementation of cascading regulations. Therefore, the more regulations there are, the higher is the frequency of interactions with the private agents, and the higher the probability that the administration will engage in corrupt practices (Dimant and Tosato 2018).

In the auction model, corrupt officials carry out an efficient auction and award the authorization to clients offering the highest bribes. Those who can offer the highest bribes have the smallest costs. In this way, bribery reproduces the outcomes of a market and there are no efficiency losses since no more than a redistributive transfer occurs between the firm and the bureaucracy. Again, this argument holds only if the bureaucrats do not have the power over the multiplication of laws and licenses and as long, the highest bidder is indeed the most effective one. As pointed out by Bardhan (1997), inefficiency may result if the bureaucrat's decision is influenced by considerations other than the highest bribe. Those who win contracts are often those who know the officials personally. Usually, they are not the ones who are the most economically effective, but those who are the most efficient in bribe-giving. Besides, resources are wasted to keep the secrecy of corrupt deals. Lastly, when revenues are not collected by the treasury but by corrupt officials, the opportunity to reduce distortionary taxes or to provide more in public services is lost. This results in an excess burden of unevenly distributed taxation.

Even when the unrealistic conditions of the two models above are met, corruption may still slow down the firms. Ahlin and Bose (2007) developed a model in which license applicants can re-apply to a new official in the hope of being served honestly. The model overturns efficient corruption results. Rather than speeding up licensing, bribery gives corrupt officials an incentive to delay. It also may result in inefficient firms being licensed instead of efficient ones. Therefore, bribery results in the inefficiencies of misallocation and delays. The fundamental weakness in efficiency-enhancing corruption reasoning is the implicit assumption that the government failure that corruption allows avoiding is exogenous and unrelated to corruption, when, in fact, it may well be put in place and maintained by corrupt politicians precisely because of its corruption potential (Aidt 2003). Moreover, one side of the deal may be forced to strike a deal on unacceptable conditions to mitigate the risk of expropriation. The resulting insecurity of property rights prevents corruption from improving efficiency. This mostly affects new entrants, since starting a business often requires dozens of permits and licenses. Second, lacking insider contacts, new firms may be pressured to pay high bribes to secure such authorizations. Furthermore, a firm giving a bribe does not have any assurance that corrupt bureaucrats secure the deal, as it cannot go to court upon its breach. In fact, bureaucrats may demand additional bribes, blackmailing the firm with delays, finally not granting the license. Even, if bureaucrats intend to fulfill the contract, their decisions could be questioned by higher authority. Hence, instead of corruption improving the efficiency of an inflexible administration, it encourages delays and promotes uncertainty (Fig. 1).

In empirical studies the most common measure is the perceived level of corruption, which aggregates information from multiple surveys into a single country indicator, and is provided by Transparency International and the World Bank. However, more recent studies have adopted a microeconomic perspective and stressed 


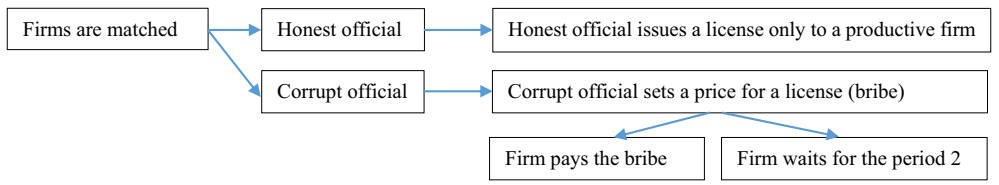

Fig. 1 Structure of the game in the 1st period (in the 2nd subperiod the process repeats itself)

heterogeneity among those who pay bribes. For example, Jeong and Weiner (2012) use the UN food-for-oil scandal finding no relationship between bribes paid and the country-level perceptions of corruption. In this line of literature, Braguinsky and Mityakov (2012) analyzed data on the revenue and market value of company cars among foreign firms. They noted that these firms were twice as transparent as firms exclusively holding domestic capital. Chavis (2013) using a survey of firms in Eastern Europe explored how firms' social networks affect their bribe payments. Lower bribes were associated with ownership by a former manager of a state-owned enterprise. The results also suggested that these networks were more important in bribe payments than firm characteristics. Cheung et al. (2012) collected a sample of corruption cases involving publicly listed firms in 52 countries and found that firm performance, the rank of politicians bribed, and bribe-paying and bribe-taking country characteristics, affected the magnitude of bribes. Bahoo et al. (2019) reviewed the literature on corruption in international business. ${ }^{1}$ They argued that strong international laws were needed to minimize the negative effect of corruption on businesses. Firms must take corruption into account when formulating their strategies to increase operational efficiency and performance as bribery may be a self-defeating strategy. $^{2}$

Svensson (2003) combined data on corruption with financial data on surveyed companies to conclude that "the ability to pay" and "the possibility of refusal" on the part of a firm can explain a large part of the volatility in the severity of bribes. This suggests that corrupt public officials often act as monopoly price discriminators, while the prices of public services are set to extort bribes. Corruption, thus, should increase bureaucratic inefficiency. This argument received empirical support in findings that firms which pay bribes are likely to spend more management time with officials (Kaufman and Wei 1999).

In contrast to previous studies on corruption, we focus not on the effects of corruption but rather on its determinants. Following a recent strand in the corruption literature, we adopt a microeconomic perspective and focus on individual firms rather than on the economy as a whole. Moreover, our empirical study is based on the newer and more comprehensive Enterprise Survey dataset, which was compiled jointly by the EBRD and the World Bank to study the business environment. Thus, compared to the previous studies, the value-added of our paper can be explained as follows. First, we investigate the issues of corruption

\footnotetext{
1 Cieślik (2020) presented a more focused review on FDI and Saputra (2019) on bilateral trade flows.

2 For a review of the relation of corruption to entrepreneurship turn to Chowdhury et al. (2019).
} 
and bureaucratic delay jointly using a unified analytical framework. Second, in contrast to previous perception-based studies, we develop a framework to investigate many aspects of corruption at the same time. Third, we study the hidden nature of corruption accounting for the self-selection process. Fourth, we use a large firm-level dataset for many developing and emerging economies.

\section{The theoretical model}

In this section, we describe the theoretical framework to develop research hypotheses subject to empirical tests. We build on the model of a stalled bureaucratic decision proposed by Ahlin and Bose (2007). The parameter $s_{j t}$ is privately known to the firm and is her 'type'. The underbar and overbar describe respectively 'low' and 'high' efficiency of supervision. The prior state of nature that firm $j$ is efficient, i.e. $s=\underline{s}$ is given by probability $q$. Let $h$ and $l$ be the social surplus coming from each additional firm of each type. The rationale for regulation is that it is socially desirable if the more efficient ones obtained licenses and thus $h>l$.

The politicians lack the information to carry out licensing and rely on information from the bureaucracy. It is better informed than the government because it has the time, resources, and specialized knowledge. The bureaucracy is assumed to earn wages normalized to zero. The bureaucracy receives an informational signal $\sigma$ about a given firm's supervision parameter $s_{j t}$. With probability $p$ the bureaucracy learns true efficiency $\sigma_{j t}=s_{j t}$. With probability $(1-p)$ the bureaucracy is unable to obtain any information on the firm in the same period and $\sigma_{j t}=\varnothing$. Since $p$ is exogenous the bureaucracy's supervision technology is taken as given. Therefore, there are four states of nature (probability, outcome):

$$
\begin{array}{lrlrl}
p q, & \sigma & =\underline{s} \wedge s=\underline{s}(1-q) p, & \sigma & =\bar{s} \wedge s=\bar{s} \\
(1-p) q, & \sigma=\bar{\emptyset} \wedge s=\underline{s}(1-q)(1-p), & \sigma=\emptyset \wedge s=\bar{s}
\end{array}
$$

If the bureaucracy fails to observe anything, that is $\sigma_{j t}=\varnothing$, then it does not report anything. If the bureaucracy learns the true efficiency, then it can provide the government with information or it can claim that it has failed to learn anything. Thus, the government cannot curb corruption.

To account for either heterogeneity of norm-breaking or intrinsic motivation, it is assumed that there are two types of bureaucrats. The first type, which is matched with the firm with probability $v$, will not collude. This parameter is publicly known while the specific type is private information. This informational setting results in the principal-agent problem. The optimal strategy for the honest part of the bureaucracy is to service productive firms in the first period. The remaining part of the bureaucracy is corrupt and maximizes personal gains. They are assumed to have full bargaining power. The firms are randomly matched with bureaucrats. In the first subperiod the bureaucrat, if honest, awards the productive firm the license before the unproductive one, if corrupt, announces the price for 
the license. Each firm decides whether to wait until the next period or to accept the offer. In the second subperiod, the process repeats.

The parameters are: $h$ and $l$-social surplus coming from additional productive and unproductive firm, $\beta$-discount factor, $M$-number of firms, $Q-\mathrm{a}$ fraction of productive firms, $\lambda$-number of licenses, $v-$ a fraction of officials who are honest.

Let us consider the resulting sequential equilibria. The case of honest bureaucracy is straightforward as all the productive firms get licenses. This is the first best solution given the inefficiencies already present in the lower than the optimal number of licenses. If some bureaucrats are corrupt then the firm matched with them decides whether to pay the demanded bribe. The firm chooses to pay any bribe up to the value of the license. Knowing this, the corrupt agent either sets the price to reap a high bribe from the productive firm or a low bribe to reap all the bribes. The relative value of choices depends on how many firms are left in the next period. Note that unproductive firms expect no surplus from the license in the second period. They are either denied the license if they meet an honest bureaucrat or they are charged their maximum price which is the full value of the license. The productive firm has a valuable option of waiting expecting to have a chance of meeting the honest bureaucrat in the next period. The price is lower the more honest bureaucrats there are and the higher is the corrupt bureaucrats' bribe in the next period. Corrupt bureaucrats perfectly bribe discriminate among firms, rather than charging a single price for the license. Each bureaucrat has a fixed number of licenses, $\lambda_{t} M$. It is also assumed that:

$$
q<\lambda_{t}<1-q
$$

The left-hand side of the assumption implies that it is optimal to give more licenses than to the productive firm alone since a certain number of unproductive firms $\lambda_{t}-q$ also increases the social surplus. In other words, the assumption means that the bureaucrat can use up his entire supply of licenses on unproductive firms alone. It is also assumed that:

$$
h>l / \beta
$$

Thus, it is more socially efficient to license a productive firm with a delay than to grant one in the first period to an unproductive firm. This is the incentive to save licenses for productive applicants.

The fraction $v$ of honest bureaucrats aim to maximize social surplus. If $v=1$, bureaucrats issue $q M$ licenses to productive firms and $\left(\lambda_{t}-q\right) M$ licenses to unproductive firms, all in subperiod 1. Thus, all productive firms and as many as possible unproductive firms are licensed. If $v$ is less than one, honest bureaucrats behave differently. Their highest priority firms are $q M$ productive ones in subperiod 1 and they do their best to service all of them. Their second priority candidates, under the assumption (2), are any productive ones that may be re-applying in subperiod 2. If they expect that corrupt bureaucrats will have serviced no productive firms, they expect that $(1-v) q M$ productive firms will approach them in the second subperiod. Consequently, they retain some or all their remaining $(1-v) q M$ licenses. They will 
have enough licenses to issue all the productive applicants if $\left(\lambda_{t}-q\right) M \geq(1-v) q M$. After some recalculation:

$$
v \geq v_{H} \equiv 2-\frac{\lambda_{t}}{q}
$$

If $v \geq v_{H}$, all productive applicants who encounter an honest bureaucrat are supervised; any left licenses belonging to honest bureaucrats go to unproductive firms in the first subperiod. In the other case, when $v<v_{H}$, only a fraction of productive applicants meeting an honest bureaucrat get a license:

$$
\theta\left(\lambda_{t}, q, v\right)=\min \left\{\frac{\lambda_{t}-q}{(1-v) q}, 1\right\}
$$

Corrupt bureaucrats maximize their income when giving out licenses. Since the bureaucracy can correctly assess productivity, each bureaucrat matched with a firm perfectly price discriminates his bribe. Since the second subperiod is final, they can earn $l$ from unproductive and $h$ from productive firms. These correspond to firstsubperiod payoffs of $\beta l$ and $\beta h$, respectively. In subperiod 1, unproductive firms are again willing to pay $l$, since they do not expect any surplus in subperiod 2 .

Productive firms are not willing to pay the full amount in subperiod 1 if they expect to encounter honest bureaucrats in the next period. Thus, they expect a surplus of $h$ discounted by $\beta$ and the probability of encountering and being serviced by an honest bureaucrat, $v \theta$ and they are willing to pay:

$$
B=h(1-\beta v q \theta)
$$

This willingness to pay is lower the higher is $v, \theta$, and $\lambda_{t} / q$.

Corrupt bureaucrats can thus earn $B$ and 1 ( $\beta h$ and $\beta l$ ) from selling licenses to unproductive and productive firms, respectively, in subperiod 1 (subperiod 2$)$. There are two cases to consider. If $B<1$, then the most lucrative firms are the second subperiod productive ones and the next most lucrative are the first subperiod unproductive ones. Each corrupt bureaucrat then saves licenses for the expected number of productive applicants and sell the remaining ones to the first subperiod unproductive ones. Since bureaucrats are homogenous given their type, none of them services productive firms in the first subperiod. Thus, the number of productive applicants in the second subperiod equals $(1-v) q M$.

The second case requires that $B>1$ In this case, corrupt bureaucrats issue licenses to all productive candidates in the first subperiod. The remaining licenses are sold to unproductive candidates in the first subperiod and this is the most efficient allocation given the assumptions. It can be shown that the condition $B<1$ is equal to:

$$
v>v_{L} \equiv \frac{h-l}{h-1+\beta q\left(\frac{\lambda}{q}-1\right)} \text { as long as } \lambda_{t}<q\left(2-\frac{h-l}{\beta h}\right)
$$

The last assumption also confirms that $0<v_{L}<v_{H}$. 
If $v_{L} \leq v$, an equilibrium exists in which corrupt bureaucrats service only unproductive firms in the first subperiod. The equilibrium involves a delay and misallocation for $v \in\left[v_{L}, v_{H}\right)$ and solely a delay for $v \in\left(v_{L}, 1\right)$. If $v<v_{L}$, all bureaucrats are efficient. Hence, the equilibrium exists implying $B<1$ for $v \in\left[v_{L}, 1\right)$ in which corrupt bureaucrats overlook productive firms in the first subperiod in favor of unproductive ones but hand out licenses only to them in the second subperiod. Hence a delay occurs.

The intuition behind Ahlin and Bose (2007) model is that productive applicants have an outside option, - the possibility of waiting until an honest bureaucrat is matched with them and thus they are less willing to pay a bribe in the first period. As a result, the bribe cannot be easily extorted. However, since the government cannot carry the supervision licensing on its own and is unable to assess the reasons for the lack of license, the bureaucracy can delay the productive firm until the second period. In this first period, unproductive candidates pay more in bribes and get the licenses in the place of productive candidates, even though licenses are worth more to the latter. Thereby corruption lowers efficiency and hurts the economy. Based on this discussion, the model predicts that licensing procedures induce bureaucratic delays that generally coincide with a higher level of corruption-higher obstacles and higher bribe payment as bureaucrats can price discriminate the firms better than the government which faces the asymmetric information problem and is unable to abate the bribe payment extortion in the administrative procedure.

Based on the aforementioned model, the following hypotheses are validated empirically in our study:

H1 Corruption as an obstacle and the bribe tax are higher for firms that spent more time dealing with officials.

H2 Corruption as an obstacle and the bribe tax are higher for firms waiting longer to get a license.

H3 Corruption as an obstacle and the bribe tax are higher for firms with more inspections.

H4 Corruption as an obstacle and the bribe tax are lower for more productive firms.

We also employ a series of hypotheses verifying the behavior of bureaucrats trying to bribe discriminate firms according to their ability to pay, their knowledge of the bribery system, and bargaining power:

H1 Corruption as an obstacle is lower for larger firms, but the bribe tax is higher.

$\mathrm{H} 2$ Firm age is associated with lower corruption as an obstacle and the bribe tax is lower.

H3 Corruption as an obstacle and the bribe tax are lower for the state- and foreignowned firms.

H4 Corruption as an obstacle and the bribe tax are higher for firms limited to the domestic market. 
H5 Corruption as an obstacle and bribe tax are higher for firms doubting courts fairness.

H6 Corruption as an obstacle and bribe tax are higher for firms reporting taxes to be an obstacle.

\section{Empirical methodology}

Two variables related to corruption are used in our analysis: the perception of corruption as an obstacle and the actual bribe tax paid by the interviewed companies. Our model has the following specification:

$$
\begin{aligned}
& \text { Corruption as an obstacle }_{i t} \text { (OR) Bribetax } \text { it }_{1} \\
& =a_{0}+\beta_{1} \text { firmsize }_{i t}+\beta_{2} \text { firmage }+\beta_{3} \text { productivity }_{i t}+\beta_{4} \text { stateowned }_{i t}+\beta_{5} \text { foreign }_{i t} \\
& +\beta_{6} \text { nationalsales }_{i t}+\beta_{7} \text { time on regulations }{ }_{i t}+\beta_{8} \text { number of inspections }_{i t} \\
& +\beta_{9} \text { fairness of courts }_{i t}+\beta_{10} \text { days to license }_{i t}+\beta_{11} \text { taxes as an obstacle }_{i t} \\
& +\Sigma \gamma * \text { country dummies }+\Sigma \tau * \text { time dummies }+\Sigma \lambda * \text { ISIC sector dummies }+\varepsilon_{i t}
\end{aligned}
$$

Both dependent variables are not observable over the total continuum. The perception of corruption as an obstacle is measured on the Likert scale ranging from 0 (i.e., not an obstacle to doing business) to 4 (i.e., a major obstacle to doing business). In contrast, the bribe tax variable is censored because it represents a fraction. Therefore, it is impossible to obtain unbiased estimation results using linear regression methods, but these problems can be tackled by an appropriate estimation technique.

In the first case, corruption is seen as an obstacle to doing business, the problem of the unobservability lies in the fact that the Likert scale is discretionary and does not perfectly depict the underlying continuum of the perception of corruption, as the number of observed categories is limited. The categories on the scale can be expressed as:

$$
\begin{aligned}
& y_{i}=0 \text { for } \mathrm{y} * \leq 0 \\
& y_{i}=1 \text { for } 0<\mathrm{y} * \leq \mu_{1} \\
& \cdots \\
& y_{i}=J \text { for } \mu_{J-1}<y *
\end{aligned}
$$

where $\mu_{1}, \ldots, \mu_{J-1}$ are the estimated cutoff points ordered as: $-\infty<\mu_{1}<\mu_{2}<\cdots<\mu_{J-1}<+\infty$.

For this model, the probability function of answer $j$ from $J$ alternatives is given by

$$
\begin{aligned}
& p_{i .0}=\operatorname{Pr}\left(y_{i}=0 \mid x\right)=F\left(-x^{\prime} \beta\right) \\
& p_{i .1}=\operatorname{Pr}\left(y_{i}=1 \mid x\right)=F\left(\mu_{1}-x^{\prime} \beta\right)-F\left(-x^{\prime} \beta\right) \\
& \vdots \\
& p_{i . J}=\operatorname{Pr}\left(y_{i}=J \mid x\right)=1-F\left(\mu_{J-1}-x^{\prime} \beta\right)
\end{aligned}
$$


where $F$ is the distribution, which we assume to be logistic for the ordered logit model that we use to estimate the problem regarding the perception of corruption as an obstacle to business.

In the second case, corruption is measured as the bribe tax at the firm level that is observable only if it has been paid. It is so, when the marginal benefit exceeds the marginal cost of being corrupt. However, the opposite case in which the costs exceed the benefits is unobservable, meaning that some unknown difficulties have prevented corruption in a given firm. In other words, the costs and difficulties of prohibitively high value are not observed. To tackle this problem, we use the Fractional Logit model (Papke and Wooldridge 1996) dealing with the phenomenon of non-random sample censoring. Compared to ordinary logistic regression and Tobin's correction, it does not leave behind observations in which the bribe tax is zero.

The potential self-selection problems in the sample and the endogeneity of several variables were considered. As for the endogeneity problem, the opposite direction of the impact of the corruption on the explanatory variables (that bribes increase other firm traits) appears to be unlikely. However, self-selection concerns were addressed by Semykina and Wooldridge (2010). The authors suggest augmenting the main equation with an inverse Mills ratio term and estimating this equation using two-stage least squares (2SLS).

The data is obtained from the Enterprise Surveys jointly conducted by the World Bank, the EBRD, the European Investment Bank, the European Commission, and the Inter-American Development Bank. There were over 164,000 interviews in 144 countries in the sample (Table 1).

Unfortunately, the survey is an as-if panel data because a large fraction of firms ceased to exist. This, in turn, required the selection of new companies in its subsequent editions. Therefore, most data is pooled, though we present a comparison with the panel investigation in the robustness section. Although the credibility of the data collected by the World Bank and the EBRD is high, we cannot exclude the possibility that the answers to the question on the percentage of firm income spent on bribe payments may be underestimated due to respondents' concerns. Note that the number of missing observations is large and causes the sample size to vary. However, we found that non-responsive firms did not differ in terms of their characteristics. In addition, we found no incidence of collinearity.

\section{Estimation results}

In each regression, we use three sets of dummy variables - relating to year, country, and ISIC code for the industry of operation of each firm. ${ }^{3}$ In column (1) of Table 2 , we report our benchmark estimation results from the specification in which the perception of corruption is the dependent variable. The set of explanatory variables includes two main characteristics of the business environment (i.e. the percentage of

\footnotetext{
3 We do not report the estimation results for dummy variables as the number of such dummies is very large.
} 


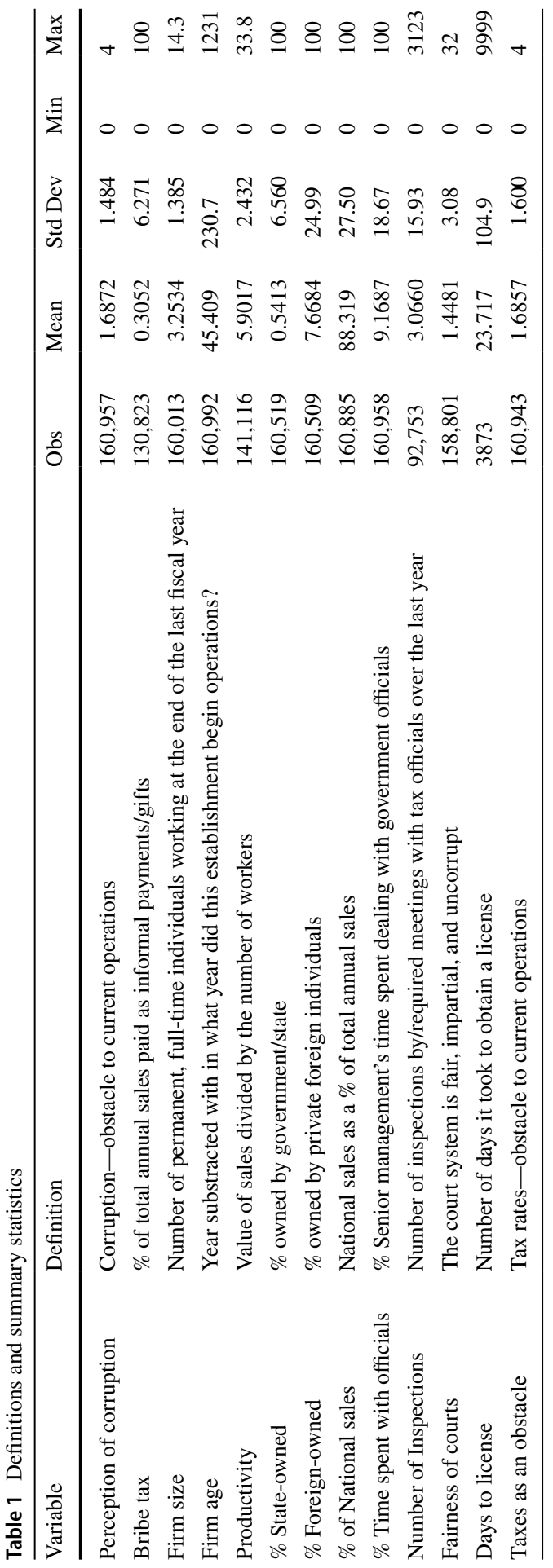




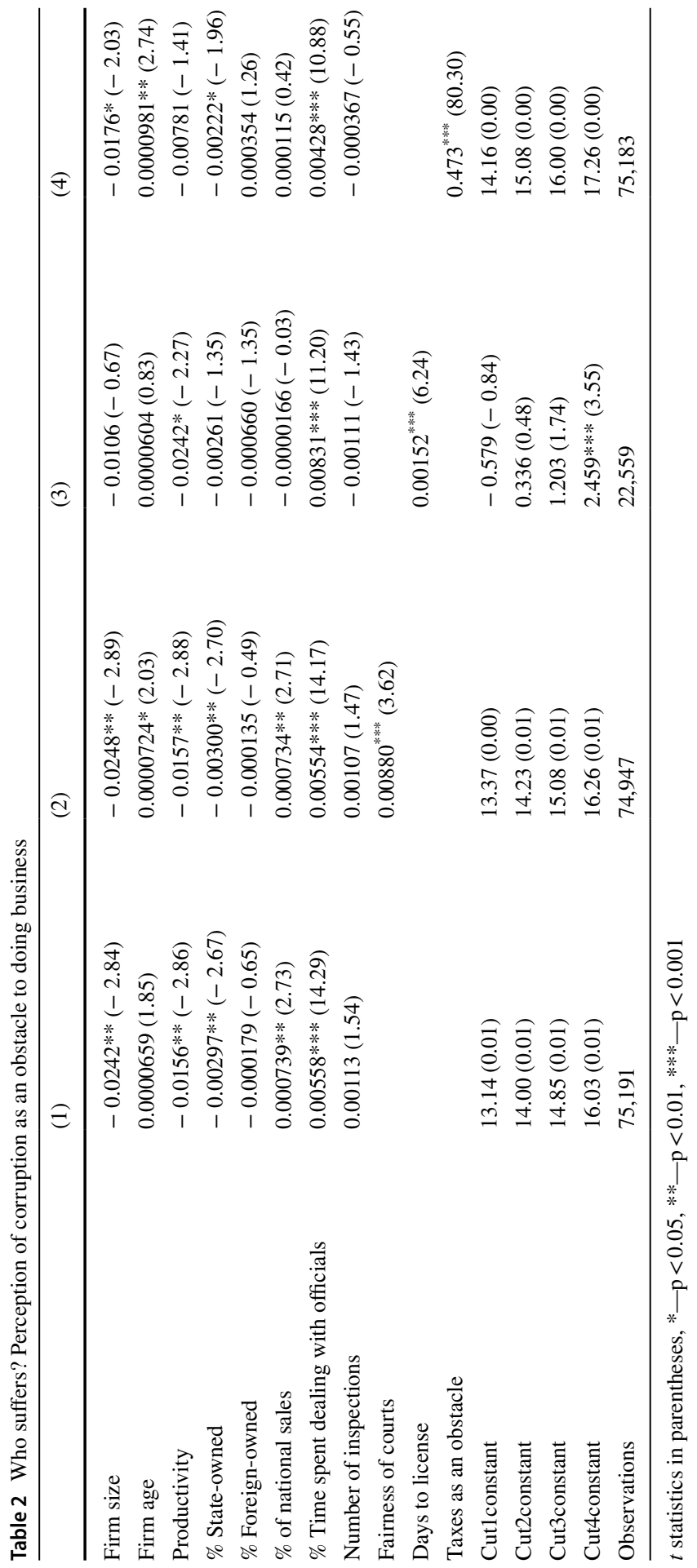


senior management's time spent dealing with government officials and the number of inspections by/required meetings with tax officials over the last year), with controls suggested by the theoretical model for a set of additional firm characteristics.

The estimated coefficients on both measures of business environment display positive signs and are statistically significant. This means that firms whose senior management spent more time dealing with government officials and in which the number of inspections is higher report a higher perception of corruption. The state ownership variable displays a negative sign and domestic market orientation, which displays a positive sign. This result means that state-owned firms are less likely to report corruption as an obstacle to their operations, because they may be better connected with public officials. At the same time, firms that have a higher percentage of sales generated in domestic markets are more likely to report corruption as an obstacle to their operations as corrupt officials may put more pressure on them. The foreign ownership is not significant. Moreover, the perception of corruption as an obstacle is associated with younger firm age, lower productivity, and smaller size measured in terms of employment. These results largely support the model and suggest that officials tend to take bribes from entities that are easier to extort and have lower bargaining power.

In column (2), we enrich the specification by adding the fairness of the court system. The estimated coefficient on this variable is positive and highly significant. However, this does not change our previous conclusions, as the estimated coefficients on the other measures of the business environment remain statistically significant. The significance of other characteristics is not affected.

Next, we report estimation results obtained from specifications in which we use alternative measures of the business environment. In column (3), we use the number of days it took the firm to obtain an operating license. The estimated coefficient on this variable is positive and significant already at the 1 percent level. In column (4), we report the results obtained from the specification in which we use taxes as an obstacle to business operations. The estimated coefficient on this variable is also positive and highly statistically significant, suggesting that corruption generally thrives in a business-unfriendly environment. In contrast to Belitski et al. (2016), though the authors study the effect of tax rates, we find that the interaction between corruption and taxes makes matters worse for the affected companies.

We run a set of robustness checks to verify our specification:

- First, we checked for the panel specification. As indicated before, the panel largely changes over time and most of the firms appear only once in the survey. We estimated panel and pooled versions of the models to find very similar results. These are reported in Table 5 in "Appendix".

- Second, we tested various sets of dummies - relating to year, country, and ISIC code for the industry of operation of each firm. Based on general-to-specific modeling we found that the full model was superior in terms of informational criteria, however, we also found that our results hold in all specifications, and therefore they are not driven by the inclusion of dummies. These results are available in Table 6. 


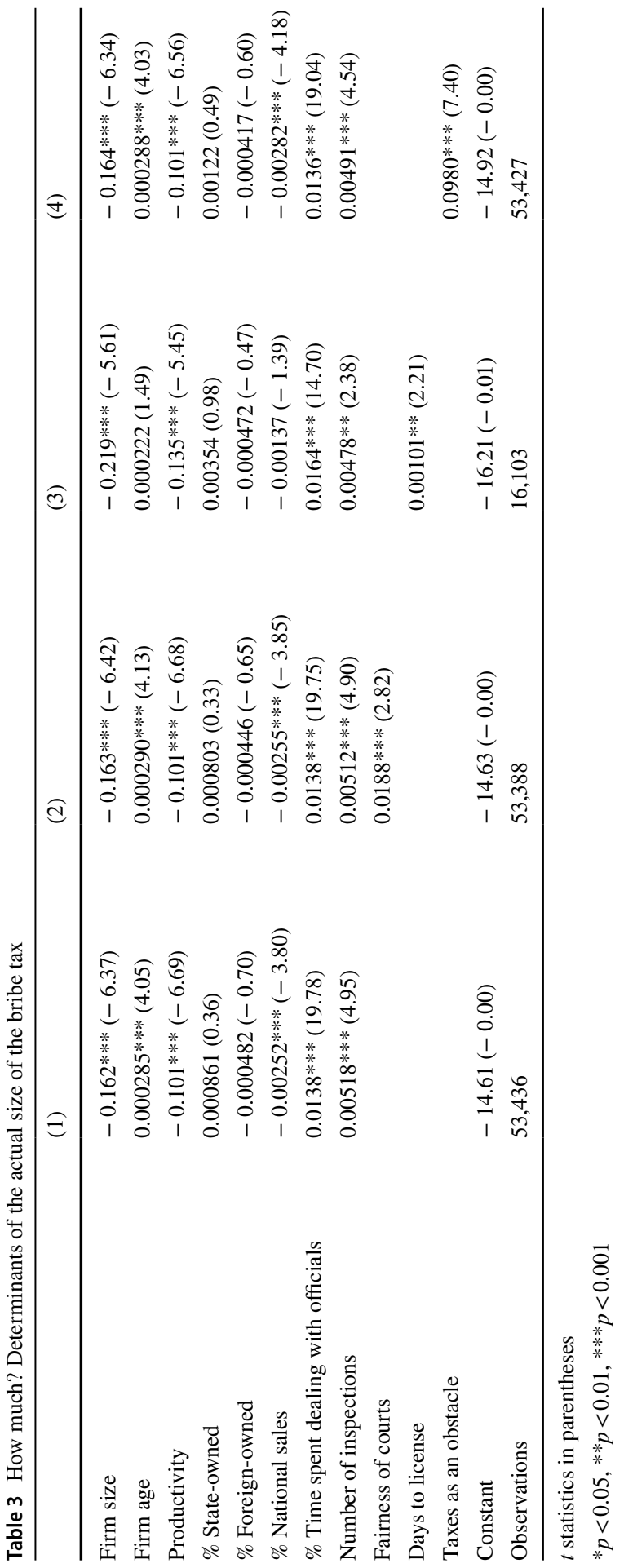


Table 3 reports the results from the specification explaining the bribe tax payments. In column (1), we report the baseline specification in which the set of explanatory variables includes the characteristics of the business environment with controls for a set of firm characteristics. The estimated coefficients on management's time spent dealing with government officials are large in economic terms, positive, and statistically significant-firms that spent more time dealing with government officials make higher corruption payments. A similar finding is that the frequency of inspections is associated significantly with higher bribe payments. As for controls, the firm size coefficient displays a significant negative sign. This means that smaller firms make higher corruption payments in relation to their incomes. Similar effects are observed for the variable representing productivity as more inefficient firms tend to pay significantly more.

In column (2), we add the variable measuring fairness of the court system. This time, the estimated coefficient on this variable positive and highly significant. In column (3), we use the number of days it took the firm to obtain an operating licensethis variable shows a significant and positive sign indicated that firms waiting longer pay more in bribes. It can be noted, however, that firms were not always asked that question in the survey and the sample size drops meaningfully in this column. In column (4), we report the estimation results obtained from the specification in which we use taxes as an obstacle to business operations. The estimated coefficient displays a positive sign and is highly statistically significant meaning that the corruption problem is also associated with tax problems. Altogether, the results point to a rather inefficient extortionary type of corruption as in Shleifer and Vishny (1993).

We also run a set of robustness checks to verify our specification:

- As a first test, we used alternative methods. Although fractional logit enables us to consider both ends of the spectrum ( 0 and 100), instead of simple truncation, we checked our specification using Tobit and complementary logistic regression to find that the results are robust to changes in the methodology. The results are available in Table 7 in "Appendix". A comparison of informational criteria supports our choice of the fractional logit model.

- The second test was to include various dummies (Table 8). Using the methodology as in the first model, we found that the results were not driven by dummies, though they improve accuracy.

- Third, we checked for the panel specification. Again, we estimated panel and pooled versions to find very similar results. These are reported in Table 9.

As noted, several concerns can be raised regarding firm self-selection and a potential endogeneity problem. Firms may be unwilling to report the actual bribe tax if they tend to meet government officials frequently. This possibility is tested in three ways. First, positive answers (including answers that the firm does not pay at all) are compared with the lack of an answer ("don't know") and a refusal to answer. Based on these comparisons, the positive responses do not differ significantly from the lack of answers.

Second, the general idea itself that firms could potentially be unwilling to report the actual bribe tax if they tend to meet government officials frequently was directly 
Table 4 Heckman selection model

(1)

(2)

(3)

\begin{tabular}{|c|c|c|c|}
\hline \multicolumn{4}{|l|}{ Bribe tax } \\
\hline Productivity & $-0.495^{* * *}(-309.68)$ & $-0.107^{* * *}(-5.34)$ & $-0.107(-0.52)$ \\
\hline Firm size & $-0.161 * *(-3.00)$ & $-0.0486^{* *}(-2.59)$ & $-0.0486^{* *}(-2.59)$ \\
\hline Firm age & $0.0000833(0.00)$ & $0.00206(0.07)$ & $0.00206(0.07)$ \\
\hline$\%$ state-owned & $0.00772 * * *(17.10)$ & $0.00479(1.22)$ & $0.00484(0.12)$ \\
\hline$\%$ Foreign-owned & $0.00437 * * *(35.68)$ & $-0.000512(-0.51)$ & $-0.000512(-0.05)$ \\
\hline$\%$ National sales & $-0.00524 * * *(-43.15)$ & $-0.00303 * *(-3.04)$ & $-0.00304(-0.30)$ \\
\hline $\begin{array}{l}\% \text { Time spent dealing with } \\
\text { officials }\end{array}$ & $0.000355 *(1.98)$ & $0.0268^{* * *}(18.70)$ & $0.0275^{* * *}(10.56)$ \\
\hline Number of inspections & $0.00209^{* * *}(14.03)$ & $0.0139 * * *(5.33)$ & $0.0204 * * *(4.23)$ \\
\hline Non-selection hazard & & $-23.42 * * *(-13.02)$ & $-23.46^{* * *}(-14.41)$ \\
\hline Constant & $-1.350 * * *(-3.99)$ & $20.76^{* * *}(12.97)$ & $20.76^{* * *}(12.99)$ \\
\hline \multicolumn{4}{|l|}{ Selection } \\
\hline Perception of corruption & $0.00817(0.85)$ & $-0.0338^{* * *}(-10.64)$ & $-0.0338^{* * * *}(-10.64)$ \\
\hline Constant & $1.968^{* * * *}(82.80)$ & $0.422 * * *(58.08)$ & $0.422 * * *(58.08)$ \\
\hline Athrho & $1.645^{* * *}(51.19)$ & $-0.000476(-0.01)$ & \\
\hline Lnsigma & $-0.263 * * *(-90.40)$ & $1.643^{* * *}(508.70)$ & \\
\hline Mills ratio & & & $-78.94(-0.08)$ \\
\hline Observations & 53,436 & 53,436 & 52,662 \\
\hline
\end{tabular}

$\mathrm{t}$ statistics in parentheses

$* p<0.05, * * p<0.01, * * * p<0.001$

tested in multiple specifications. Generally, this mechanism can be modeled using a Heckman selection model as a two-step decision: first, whether a firm engages in dealings with state officials (e.g., obtains a license or engages in a public contract) and, second, how much is paid as a fraction of total firm sales once the firm is selected. However, this approach is unfruitful because the self-selection mechanism proposed here is not significant.

Finally, we tested whether corruption corrupts in the sense that corruption has a self-enforcing nature. In environments where corruption is the norm, corruption tends to persist. If people see that others violate norms regarding corruption, they comply with their beliefs and engage in corruption. In this sense, prior beliefs about corruption are a significant self-selection factor of giving bribes. To test for this, we specify Heckman's sample selection model that jointly analyzes the incidence of an observable bribe, which is a binary outcome, and its level, as depicted by the bribe tax, which is a continuous outcome. Thus, we fit the model in which the bribe tax is determined by the variables in the models specified in Table 3 , and we assume that the bribe itself is observed if the firm itself perceives that corruption is an obstacle. Because the errors on both have correlation $\rho$, we test for this correlation and find a significant self-selection problem. 
In column (1) of Table 4, we report the results for models in which selection is not considered to be endogenously estimated using the maximum likelihood estimation method. This selection mechanism is significant and relatively important. As for the endogeneity problem, the opposite direction of the impact of the investigated variable on the explanatory variables seems to be quite unlikely. However, these concerns can be jointly considered in the self-selection model.

Thus, in (2) and (3), we expand the Heckman model to allow for the endogeneity of selection covariates by estimating the inverse Mills ratio term to calculate the non-selection hazard. This selection mechanism is significant, and the endogeneity problem is indeed present in the data. In addition, a comparison of the methods shows no significant difference in the results. Therefore, firms believing that corruption is a problem for "firms like theirs" are prone to self-selection and are more inclined to pay bribes if they believe that others pay. This result is significant and quite robust to changes in the specification.

A possible explanation for this result could be that "corruption corrupts". The expected profitability of engaging in a corrupt transaction depends on the number of other firms that are doing the same. Corrupt firms may prefer to interact with corrupt officials and continue to be corrupt if they have interacted with corrupt individuals in the past, and internalized moral feelings of guilt from engaging in bribing behavior decrease as the number of firms believed to be corrupt increases. Thus, it is more difficult to find and punish corrupt officials in environments in which everybody is corrupt. Cieślik and Goczek (2018b) show that the distant past weighs more in corruption dynamics than recent developments. However, as Tang et al. (2019) show the role of social media could aid in this oversight to put pressure from society on fraudulent officials.

\section{Concluding remarks}

We adopted Ahlin and Bose (2007) model to hypothesize that corruption is higher for less productive firms, spending more time dealing with officials, waiting longer to get a license, and inspected more frequently. To verify these hypotheses, we studied the determinants of corruption at the firm level by using the sample of 164,000 companies from 144 countries during the 2005-2020 period. In our empirical study, we used two main measures of corruption: the perception of corruption as an obstacle to doing business and the actual bribe tax payments made by individual firms.

Our first set of empirical results showed that smaller firms, with a lower share of state ownership, a higher share of domestic sales, that spent more time dealing with officials, waited longer for licenses, paid higher taxes, and perceived the courts to be corrupt, have suffered more from corruption. The second set of our empirical results showed that newer, smaller, less productive, domestic-oriented firms that spent more time dealing with government officials, that perceived the court system to be corrupt and were more frequently inspected, and suffered from delays had a larger share of bribe payments in their revenues. 
Therefore, it can be argued that firms spending more time dealing with government officials have a higher perception of corruption and make significantly higher bribe payments. The bribe payments were concentrated in firms that had less bargaining power in dealing with the state which means that administrative corruption does not ensure profitable new business opportunities, accelerate administrative procedures, or circumvent restrictive rules, under the theory of "corruption increasing efficiency". Rather, it could be argued that the firms are intentionally delayed to extort bribe payments.

These results allow for formulating several policy recommendations. Namely, firms' contacts with government officials should be minimized. Moreover, the depersonalization of these contacts is highly desirable. For this reason, administrative procedures must be simplified by reducing their number and replacing firms' direct contacts with web applications in the framework of e-administration. Transparency and social oversight can also aid this problem.

The results for endogeneity show that firms that believe that corruption is a problem for "firms like theirs" are predisposed to self-selection regarding their bribe payments. In environments in which everybody is corrupt, firms are more inclined to pay bribes. This means that it may take years or even decades to reduce corruption to a lower level. There could be a lack of successful anti-corruption campaigns because management only confirms their prior beliefs.

\section{Appendix}

See Tables 5, 6, 7, 8 and 9.

Table 5 Who suffers?

Perception of corruption as an obstacle to doing businessrobustness check to compare panel (1) and pooled (2) specifications

\begin{tabular}{lll}
\hline & $(1)$ & $(2)$ \\
\hline Firm size & $-0.652 * *(-2.62)$ & $-0.0619 * * *(-8.64)$ \\
Firm age & $-0.00311^{*}(-2.36)$ & $0.000145^{* * *}(4.36)$ \\
Productivity & $1.262 * * *(8.55)$ & $-0.0624 * * *(-14.47)$ \\
\% State-owned & $0.0563(1.67)$ & $-0.00887 * *(-8.74)$ \\
\% Foreign-owned & $0.0461 * * *(5.45)$ & $-0.000400(-1.66)$ \\
\% National sales & $0.00150(0.18)$ & $0.00106 * * *(4.38)$ \\
\% Time spent & $0.179 * * *(12.70)$ & $0.00826 * * *(23.28)$ \\
dealing with & & \\
officials? & & $0.00428 * * *(5.76)$ \\
Inspections & $0.232 * * *(10.60)$ & 81,518 \\
Observations & 58,399 & $256,192.4$ \\
AIC & $58,922.3$ & $256,304.1$ \\
BIC & $59,021.0$ & \\
\hline
\end{tabular}

$* p<0.05, * * p<0.01, * * * p<0.001$ 


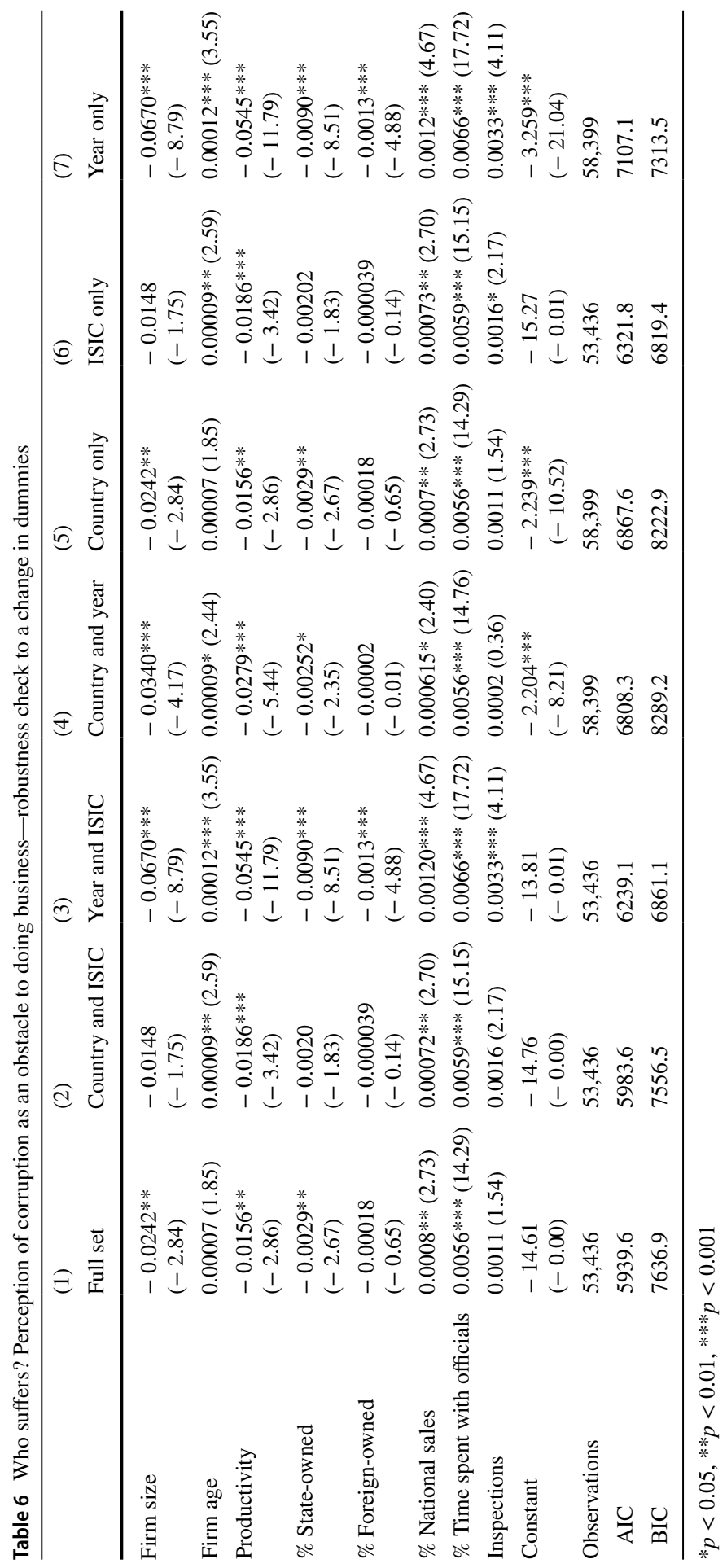




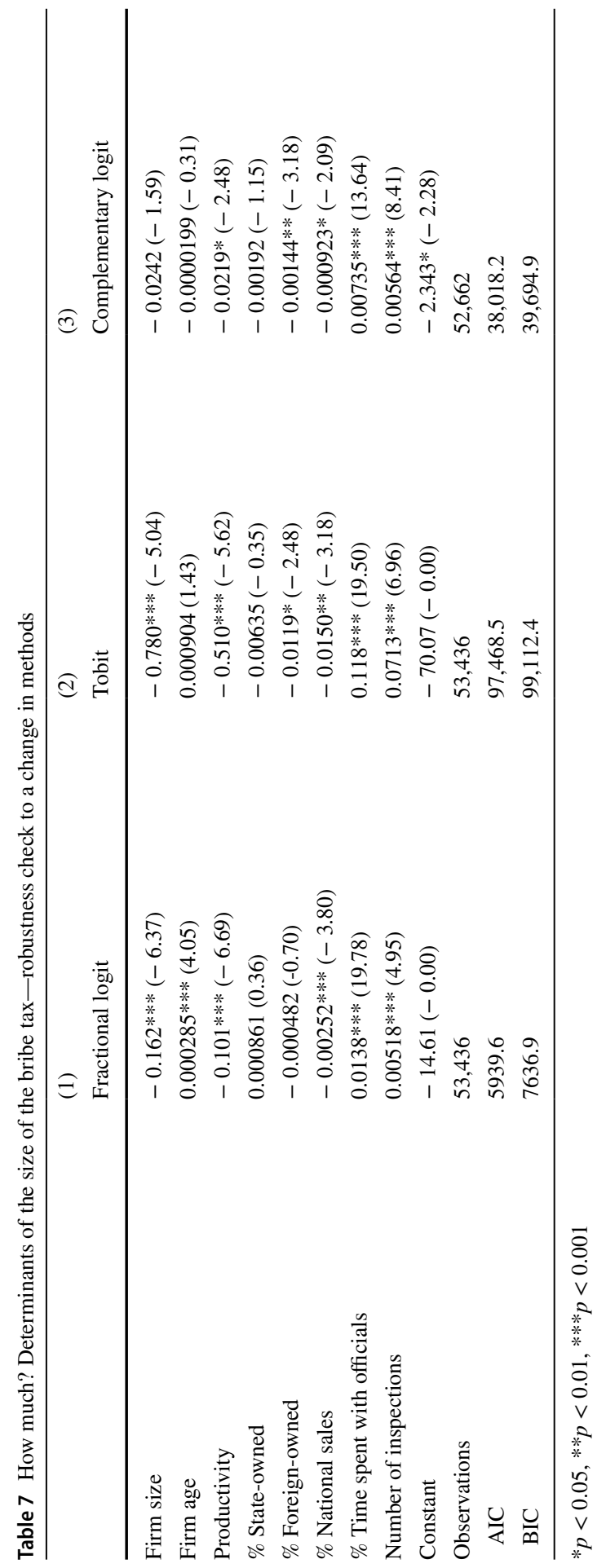




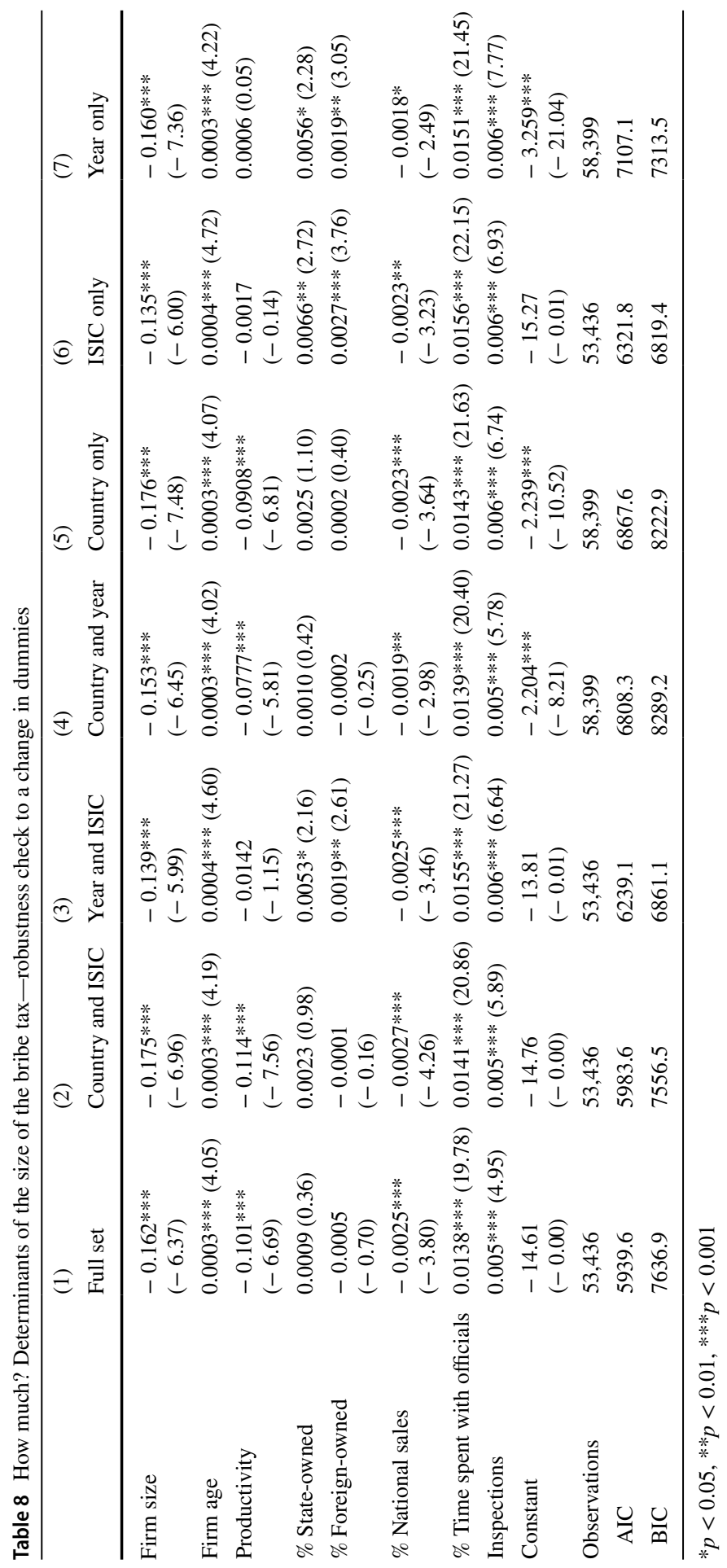


Table 9 Size of the bribe tax-robustness check to compare panel (1) and pooled (2) specifications

(1)

(2)

\begin{tabular}{lcc} 
Firm size & $-0.780 * * *(-5.04)$ & $-0.652 * *(-2.62)$ \\
Firm age & $0.000904(1.43)$ & $-0.00311^{*}(-2.36)$ \\
Productivity & $-0.510 * * *(-5.62)$ & $1.262 * * *(8.55)$ \\
$\%$ State-owned & $-0.00635(-0.35)$ & $0.0563(1.67)$ \\
$\%$ Foreign-owned & $-0.0119 *(-2.48)$ & $0.0461 * * *(5.45)$ \\
$\%$ National sales & $-0.0150 * *(-3.18)$ & $0.00150(0.18)$ \\
$\%$ Time spent dealing with officials & $0.118 * * *(19.50)$ & $0.179 * * *(12.70)$ \\
Number of inspections & $0.0713 * * *(6.96)$ & $0.232 * * *(10.60)$ \\
Constant & $-70.07(-0.00)$ & $-39.69 * * *(-15.18)$ \\
\hline
\end{tabular}

$* p<0.05, * * p<0.01, * * * p<0.001$

Open Access This article is licensed under a Creative Commons Attribution 4.0 International License, which permits use, sharing, adaptation, distribution and reproduction in any medium or format, as long as you give appropriate credit to the original author(s) and the source, provide a link to the Creative Commons licence, and indicate if changes were made. The images or other third party material in this article are included in the article's Creative Commons licence, unless indicated otherwise in a credit line to the material. If material is not included in the article's Creative Commons licence and your intended use is not permitted by statutory regulation or exceeds the permitted use, you will need to obtain permission directly from the copyright holder. To view a copy of this licence, visit http://creativecommons.org/licen ses/by/4.0/.

\section{References}

Ahlin, C., \& Bose, P. (2007). Bribery, inefficiency, and bureaucratic delay. Journal of Development Economics, $84,465-486$

Aidt, T. (2003). Economic analysis of corruption: A survey. The Economic Journal, 113(491), 632-652

Bahoo, S., Alon, I., \& Paltrinieri, A. (2019). Corruption in international business: A review and research agenda. International Business Review, 2019, 101660

Bardhan, P. (1997). Corruption and development: a review of issues. Journal of Economic Literature, 35(3), 1320-1346

Beck, P., \& Maher, M. (1986). A comparison of bribery and bidding in thin markets. Economics Letters, $X X, 1-5$

Belitski, M., Chowdhury, F., \& Desai, S. (2016). Taxes, corruption, and entry. Small Business Economics, 47, 201-216

Chavis, L. (2013). Social networks and bribery: The case of entrepreneurs in Eastern Europe. Journal of Comparative Economics, 41(1), 279-293

Cieślik, A. (2020). Determinants of foreign direct investment from OECD countries in Poland. Eurasian Economic Review, 10(1), 9-25

Cieślik, A., \& Goczek, Ł. (2018a). Control of corruption, international investment, and economic growth-evidence from panel data. World Development., 103, 323-335

Cieślik, A., \& Goczek, Ł. (2018b). Initial conditions and privatisation as causes of post-communist corruption. Post-Communist Economies, 30(1), 36-55

Dimant, E., \& Tosato, G. (2018). Causes and effects of corruption: what has past decade's empirical research taught us? A survey. Journal of Economic Surveys, 32, 335-356 
Gründler, K., \& Potrafke, N. (2019). Corruption and economic growth: New empirical evidence. European Journal of Political Economy, 60, 101810

Jeong, Y., \& Weiner, R. (2012). Who bribes? Evidence from the United Nations' oil-for-food program. Strategic Management Journal, 33, 1363-1383

Leff, N. (1964). Economic development through bureaucratic corruption. American Behavioral Scientist, VIII, 8-14

Lui, F. T. (1985). An equilibrium queuing model of bribery. Journal of Political Economy, XCIII, 760-781

Myrdal, G. (1968). Asian Drama. II. Random House.

Papke, L., \& Wooldridge, J. (1996). Econometric methods for fractional response variables with an application to 401(k) plan participation rates. Journal of Applied Econometrics, 11(6), 619-632

Rose-Ackerman, S. (1978). Corruption: A study of political economy. Academic Press.

Saputra, P. M. A. (2019). Corruption perception and bilateral trade flows: Evidence from developed and developing countries. Journal of International Studies, 12(1), 65-78

Semykina, A., \& Wooldridge, J. (2010). Estimating panel data models in the presence of endogeneity and selection. Journal of Econometrics, 157(2), 375-380

Shleifer, A., \& Vishny, R. (1993). Corruption. Quarterly Journal of Economics, 108, 599-618

Svensson, J. (2003). Who must pay bribes and how much? Evidence from a cross section of firms. The Quarterly Journal of Economics, 118(1), 207-230

Sylwester, K. (2019). Extortion or cost-reduction: Why do firms pay bribes? Journal of Applied Economics, 22, 85-101

Tang, Z., Chen, L., Zhou, Z., Warkentin, M., \& Gillenson, M. L. (2019). The effects of social media use on control of corruption and moderating role of cultural tightness-looseness. Government Information Quarterly, 36, 4

Braguinsky, S., Mityakov, S. (2012). Foreign corporations and the culture of transparency: Evidence from Russian Administrative Data, NBER Working Papers 17731.

Cheung, P., Raghavendra, R., Stouraitis, A. (2012). How much do firms pay as bribes and what benefits do they get? In Evidence from corruption cases worldwide, NBER Working Papers 17981.

Chowdhury, F., Desai, S., Audretsch, D. (2018). Corruption, entrepreneurship, and social welfare. In Corruption, Entrepreneurship, and Social Welfare (67-94). Springer, Cham.

Huntington, S. (1968). Modernization and corruption. In Political order in changing societies, (New Haven: Yale University Press), pp. 59-71.

Kaufmann, D., Wei, S. (1999). Does grease money speed up the wheels of commerce? NBER Working Papers 7093.

Publisher's Note Springer Nature remains neutral with regard to jurisdictional claims in published maps and institutional affiliations. 